\title{
DEVELOPMENT OF A PROJECT MANAGEMENT METHODOLOGY FOR THE CONSULTING ENGINEERING INDUSTRY
}

\author{
J.T. Labuschagne ${ }^{1}$ and H. Steyn \\ Graduate School of Management Technology \\ University of Pretoria, South Africa \\ herman.steyn@up.ac.za
}

\begin{abstract}
This paper describes the characteristics of a project management methodology that is currently used in the consulting engineering industry in South Africa. Based on currentlyused methodologies in other industries, and on a Delphi survey conducted in several consulting engineering companies, guidelines for a project management methodology for the consulting engineering industry are proposed. Respondents of the survey were in full agreement on typical project life cycle phases. They were also in agreement that a lack of project management knowledge and maturity prevents the successful implementation of such a methodology in a company. Lastly, the respondents agree that, by applying a project management methodology in the South African consulting engineering industry, more consistent results regarding time, cost, and quality could be achieved.
\end{abstract}

\section{OPSOMMING}

Hierdie artikel beskryf die karakteristieke van 'n projekbestuurmetodologie wat tans gebruik word deur die raadgewende ingenieursbedryf in Suid-Afrika. Gebaseer op metodologieë wat tans in ander bedrywe gebruik word, en op 'n Delphi ondersoek in verskeie raadgewende ingenieursmaatskappye, word riglyne voorgestel vir die raadgewende ingenieursbedryf. Respondente het eenstemmigheid oor tipiese fases in die projeklewensiklus. Hulle het ook saamgestem dat 'n gebrek aan projekbestuurkennis en -volwassenheid die suksesvolle implementering van so 'n metodologie voorkom. Ten slotte het die respondente saamgestem dat, deur die toepassing van 'n projekbestuurmetodologie in die Suid-Afrikaanse raadgewende ingenieursbedryf, meer konsekwente resultate ten opsigte van tyd, koste, en gehalte behaal kan word.

\footnotetext{
${ }^{1}$ The author was enrolled for an MEng (Project Management) Degree at the Graduate School of Management Technology, University of Pretoria.
} 


\section{INTRODUCTION}

\subsection{Background}

Project management is a complex undertaking, with many stages and processes. It should follow the full business life cycle, from definition and justification of the project, through to delivering demonstrable benefits for the company. A methodology is a set of methods, processes, and practices that are repeatedly carried out to deliver projects on time and within budget, while meeting all specifications and expectations. Nicholas and Steyn [1] define project management methodology as "the framework or process that specifies steps and tasks required or recommended by an organisation to manage a project". The key concept is that the same steps are repeated for every project conducted, and by doing that, efficiencies are achieved.

The recent boom in the mining and construction industries has had a positive effect on the consulting engineering industry in particular. Timely completion of projects within budget and on specification is of strategic importance to consulting engineers to ensure good market share in the engineering industry. According to preliminary investigation, project failures with respect to time and cost are attributed to a misalignment of project objectives between consultants and client, miscommunication between design and construction departments/contractors, absence of project management practices, and dissatisfaction on the part of project sponsors.

There is a need to define and implement a project management methodology that specifies the steps and tasks that are required to manage consultation-type projects in a consistent manner. The objective of such a methodology or model will be to ensure that 'good' and 'best' project management practices are identified and applied across all projects in a typical consultation engineering company.

\subsection{Current state of the industry}

The Gautrain project, the construction of further power stations for ESKOM, and the building and upgrading of stadiums for the 2010 Football World Cup, are some of the sizeable projects that - coupled with the rapid economic growth the country has experienced with recent record-low interest rates and the relatively low cost of capital created an unprecedented demand for consulting engineers. These projects rely heavily on consulting engineering firms to assist them to assure that the projects are conducted in accordance with best practices.

\subsection{The research problem}

The requirements for a project management methodology, and the status of project management practices in the local and international engineering consulting industry, are unknown due to the limited amount that is being published on the subject. From the limited unofficial information available, it seems that cost and time overruns are being experienced in the local consulting engineering industry. This industry has a real need to define and implement a project management methodology to ensure that all future projects are conducted with the same intensity, and to ensure increased performance with respect to schedule, budget, and quality.

The following research questions were answered during this study, pertaining to the definition and use of project management methodology in the consulting engineering industry in South Africa:

- What are the characteristics of existing/available project management methodologies?

- What are the pros and cons of the different methodologies or types of methodologies in general?

- How applicable are the available methodologies to the consulting engineering industry? 
- Which project phases will be required for a consultation project management methodology?

- Which phase-specific deliverables and sign-offs are required for the project management methodology?

A further objective is to design a project management methodology for a specific consultancy.

\section{THEORY AND RESEARCH REVIEW}

\subsection{Literature on project management in the consulting engineering industry}

Limited literature is available on the status of project management, project management methodologies, and performance of consulting projects in the engineering environment. Condon and Hartman [2] identified the drivers for optimistic project estimates from the project sponsor/client perspective as: a belief that all will go right (naivety), lack of knowledge of past project performances (ignorance) and the need to be optimistic to make a project possible (deception). They further included optimistic estimates, mistakes in estimates, and negotiations with contractors for a lower price without reducing the project deliverables. They also identified factors such as underestimating the cost of delays, insufficient provision for contingencies, design changes, exchange rates, and technology innovation.

- $\quad$ Project management practice for consulting engineering type projects

Cost and time overruns for capital expenditure projects seem not to be confined to the mining industry. Flyvbjerg et al. [3] studied 258 major transportation infrastructure projects, and found an average cost overrun of $28 \%$, with $90 \%$ of the projects overspending. A study of 60 large engineering projects by the International Program in the Management of Engineering and Construction (IMEC) found that $18 \%$ of the projects incurred extensive cost overruns [4].

Project management in the $21^{\text {st }}$ century is expected to change from 'getting the job done' to Strategic Project Leadership $®$, with the notion of 'creating a competitive advantage and winning in the market place' applying, and project management being used as a competitive weapon [5]. Furthermore, rapid changes in socio-economic-political environments cause a shift in project contexts and how they are executed [6]. One of these contextual changes is to include the principles of sustainable development as part of project management methodologies and life cycle frameworks [7].

- Current research on project management methodologies

Cooke-Davies and Arzymanow [8] indicated that the most highly-developed project management models were found in the petrochemical and defence industries. They concluded that it seems that the longer an industry is subject to competitive pressures to perform, the more mature its project management practices are likely to become [8]. The maturity of project management practice in the mining industry is not mentioned in any of their references.

- Project management methodologies currently in use

According to Labuschagne and Brent [7], a benchmarking study confirmed that companies that are successful in project management use a simple, well-defined project management framework. A number of commercial project management methodologies are being used by government, business, and non-profit organisations. Among these models are the P2M2 [9], Staged Life Cycle Framework [7], and the SASOL Business Development and Implementation (BD\&l) model [10]. A long list of additional methodologies could be added here, but the majority of those named above are aligned with the worldwide standards for project management, PMBOK $\circledast$ (Project Management Body of Knowledge) and PRINCE2 $®$ (Projects in Controlled Environments), and are the most commonly used in the engineering industry. 
The variety of project management methodologies that have been defined and are being used might indicate that a 'one size fits all' approach is not appropriate to fulfil all the project development and execution life cycle requirements [19]. White and Fortune [11] furnished proof of that statement when they found that, out of 206 project management methodologies used in their survey, 128 were in-house - i.e. more than $50 \%$. Only 23 and 14 of the respondents used the formal methodologies PRINCE and PRINCE2 respectively.

\section{THEORETICAL FRAMEWORK}

\subsection{Similarities in currently used project management life cycle methodologies}

Figure 1 shows the life cycle phases of a number of project management methodologies in relation to each other. All the mentioned methodologies begin with an initiation phase, followed by a planning phase. The next phase could be seen as an execution phase, followed by a close out phase. These four phases are known as the project management process groups [12].

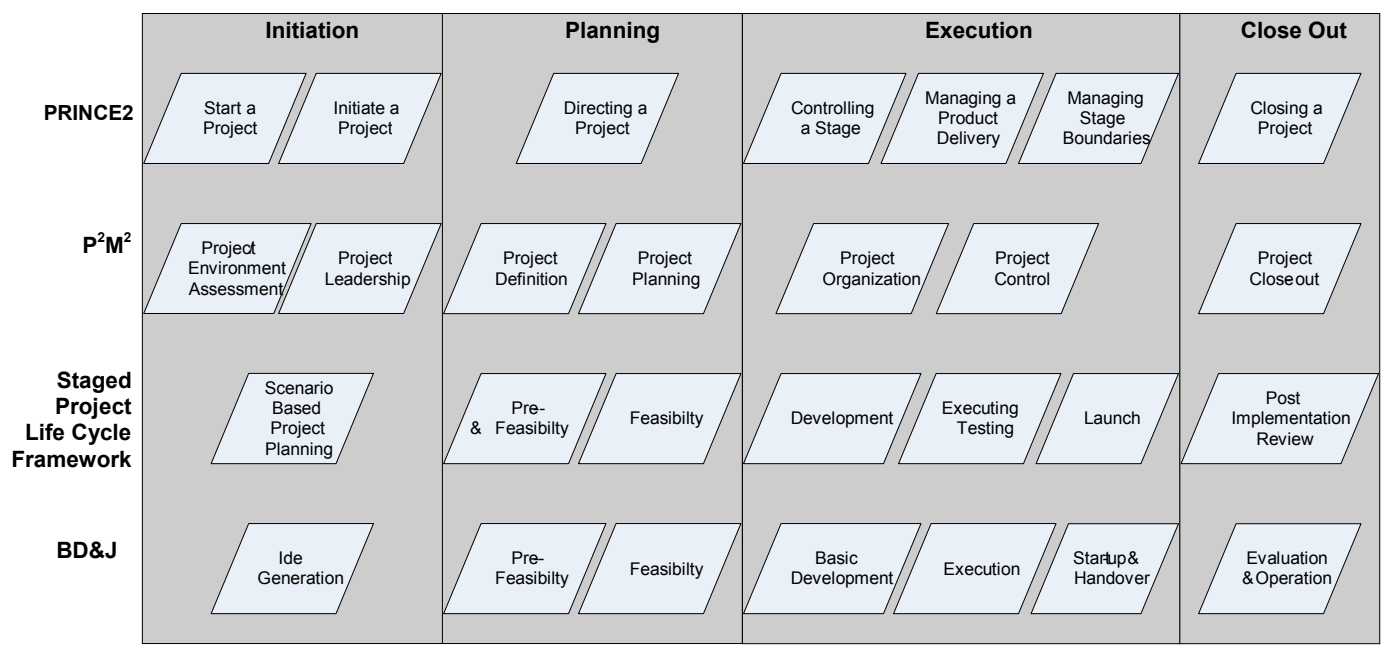

Figure 1: Life cycle phases of different project management methodologies

\subsection{Suggested construct for a generic project life cycle methodology}

Based on the currently used project management methodologies indicated in Figure 1, a framework of important elements were generated, indicated in

Figure 2. The elements of the project development and execution construct are: Project life cycle phases, Required tasks and deliverables, Signoffs/approvals, and Stakeholders.

\subsection{Defining a consulting engineering industry-specific project management methodology}

Based on the framework and elements defined in Figure 2 for a consulting engineering project management methodology, a detailed project management methodology can be defined for the consulting engineering industry with the aim of satisfying the needs of a specific consultancy. Interviews were conducted with senior project representatives of the consultancy after establishing a preliminary project management methodology to ensure applicability of the model within the company. The framework of the resulting life cycle methodology is shown in Figure 3. 


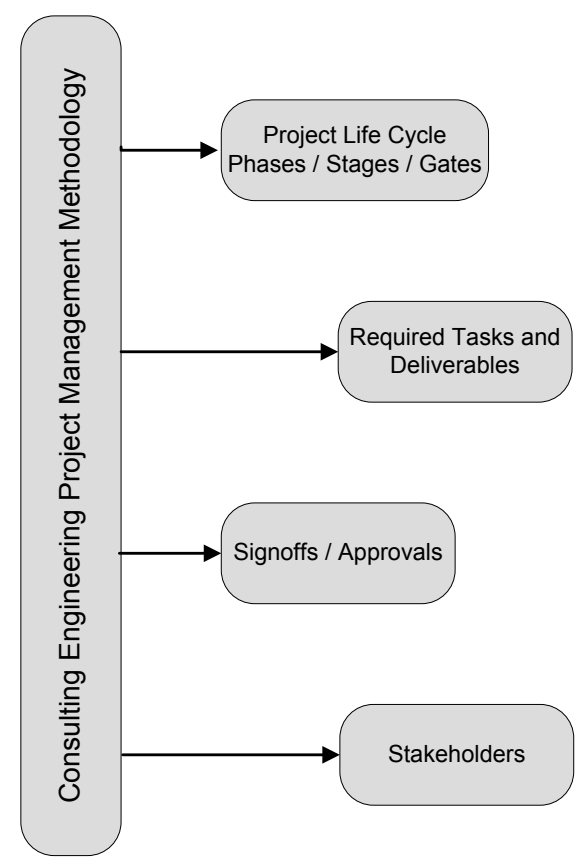

Figure 2: Framework for the project development and execution life cycle methodology

Based on the literature, and confirmed through interviews, the proposed project management methodology consists of four stages:

- Project initiation phase

- Project planning phase

- Project execution phase, and

- Project close-out phase

Each phase ends with a phase review, with signoffs from the client, sponsor, business unit manager, and project manager, before moving on to the next phase. The indices that are accounted for across all of the project life cycle phases are: business, engineering, operation, project management, key deliverables, sponsor, and quality control. The detail activities for each of the phases are shown in Table 1. This table was used as the basis for a survey to validate the methodology, and to obtain further information relevant to project management methodologies in consulting engineering.

\section{RESEARCH DESIGN AND METHOD}

\subsection{Survey method}

Due to the exploratory nature of this study, the Delphi technique [13] was selected to determine the characteristics of the project life cycle methodology. The Delphi technique was applied during two rounds of questionnaires. The first round consisted of open-ended questions to allow maximum opportunity to obtain all perspectives from experts on the definition and use of a project management methodology in the industry. During the second round, answers from the first round were condensed into scalable questions to get an indication of conformance on all the topics with relevant importance. A similar approach was used by Scholl et al. [14]. The questionnaires were distributed to project managers in the South African consulting engineering industry with between 5 and 10 years of experience. Two rounds of questionnaires were considered sufficient for the purpose of this study. 


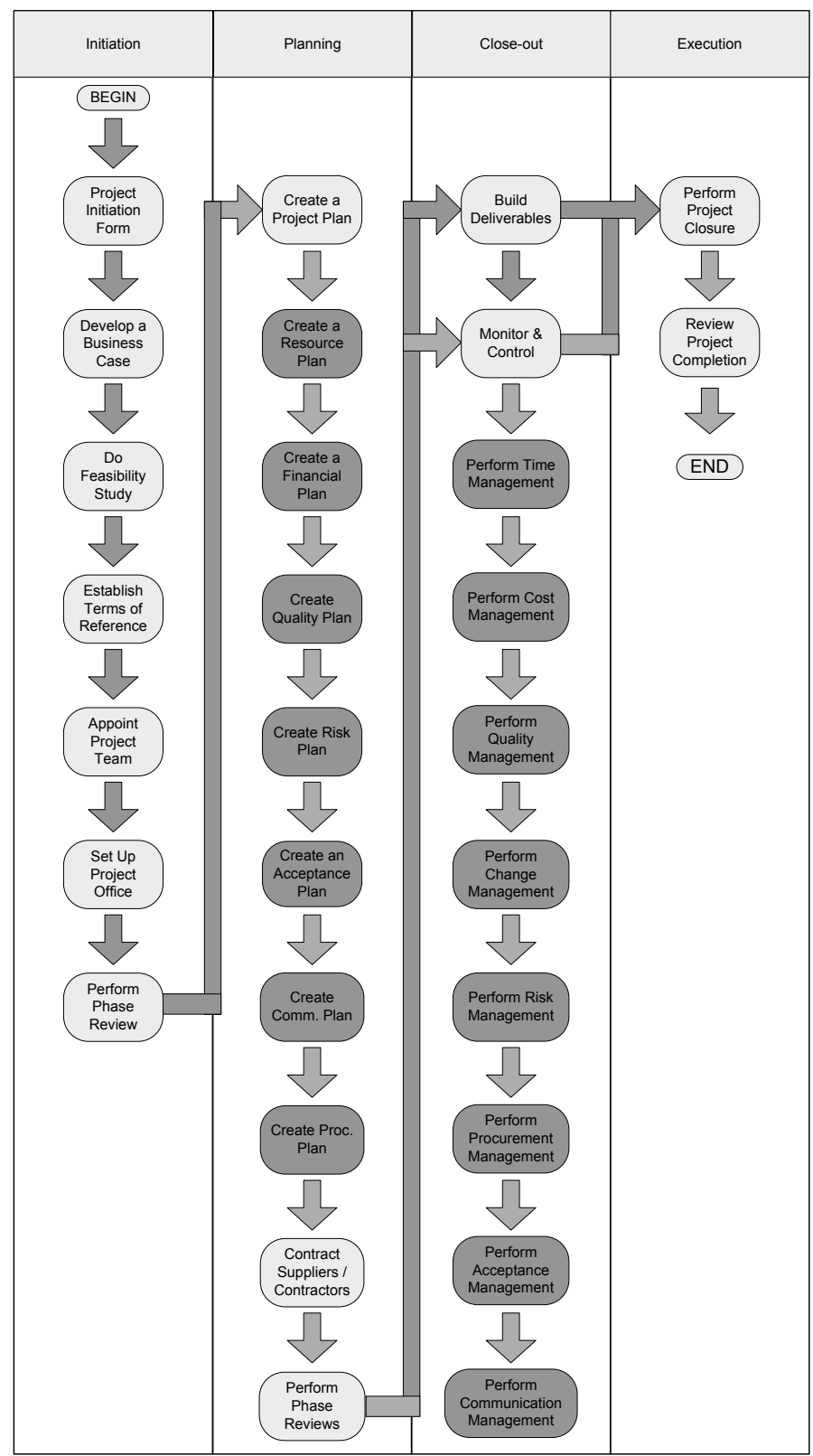

Figure 3: Defined framework for the project management methodology

\subsection{Development of a survey for round 1}

An initial survey was developed and pre-tested, using the opinions of the study leader and an external project manager. The final survey questions for round 1 were derived by taking consideration of the comments from the pre-testing, as well as considering the research questions for this study. The research questions for round 1 of the survey were as follows:

- What are the most pressing and challenging issues when applying a project management methodology for projects in the South African consulting engineering industry?

- Which typical project life cycle phases are required for consulting projects? 
- Which major aspects need to be considered for each project life cycle phase?

- Which factors inhibit the application of a project management methodology in practice?

- How can a consulting organisation in South Africa deal effectively with the application of a project management methodology for projects?

- How can the application of a project management methodology enhance the global competitiveness of the South African consulting engineering industry?

\subsection{Sample selection}

Determining the size of the respondent panel is always a debatable issue. However, considering the arguments that a Delphi survey should not be viewed as an opinion poll, as well as the broad view expressed by authors in this field, it seems that a panel between 7 and 20 might be appropriate, at least for the first round of the questionnaire [15]. Other authors confirm that 7 to 12 respondents are sufficient [16] [17] [18]. A total of thirteen experienced participants were identified who are currently employed as project managers for consulting engineering companies in South Africa. The second round of questionnaires was sent to all the respondents from the first round.

\section{DATA GATHERING AND ANALYSIS}

\subsection{Data gathering process}

The selected respondents were contacted via e-mail. The purpose of the research, its methodology, definitions, number of rounds, confidentiality, and feedback after the study were explained to the thirteen selected respondents. The questionnaire for round 1 of the study was attached to the e-mail message. The respondents were reminded to complete the round 1 questionnaire, and six responded after four weeks. The data was analysed, and the questionnaire for round 2 of the study was drafted and sent to the seven respondents. All seven respondents responded and the data could be analysed.

\subsection{General information on respondents}

A request for general information on the companies and projects of the respondents was made during the first round of questions. The following information was obtained:

- The annual turnover of all but one of the respondent companies was in excess of R50 million; the remaining one was between R1 million and R10 million

- The types of engineering activities were software development, mechanical, thermal fluid, and project management

- The average respondent had more than five years' project management experience;

- The average size of projects exceeded R1 million;

- The average duration of projects exceeded one year;

- Contracting strategies ranged from fixed price to target price and cost reimbursable plus fee.

The methodology employed by Scoll et al. [14] was used to analyse the data from round 1 in order to define the questions for round 2 . The following methodology was used:

- List all responses from round 1

- Identify a list of keywords from respondents

- Categorise the keywords from respondents

- Identify categories that occur twice or more

- Formulate Likert scalable questions from the aforementioned categories that occurred twice or more.

The round 2 questionnaire was sent to the six respondents from the first round. An example of a Likert scalable question was as follows: 


\begin{tabular}{|c|c|c|c|c|}
\hline & Project initiation & Project planning & Project execution & Project close-out \\
\hline 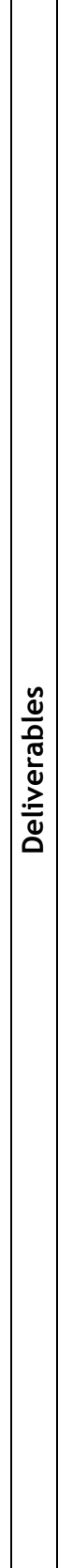 & 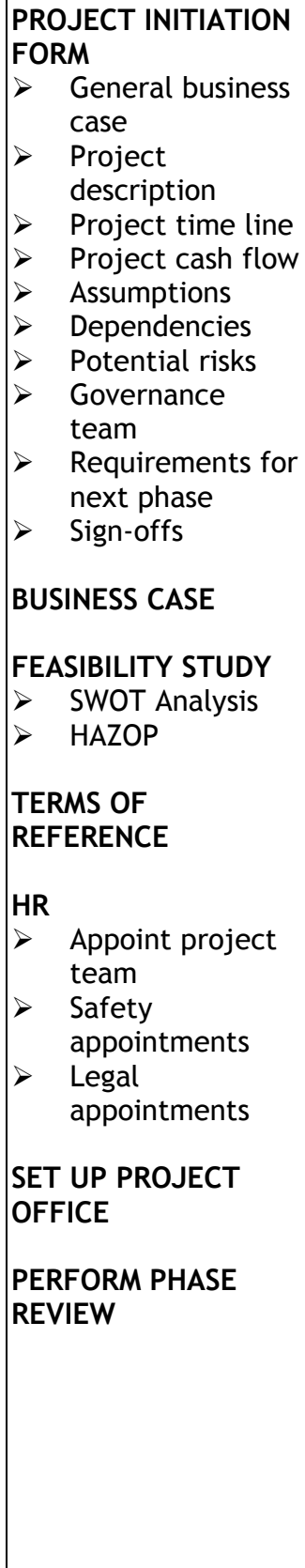 & 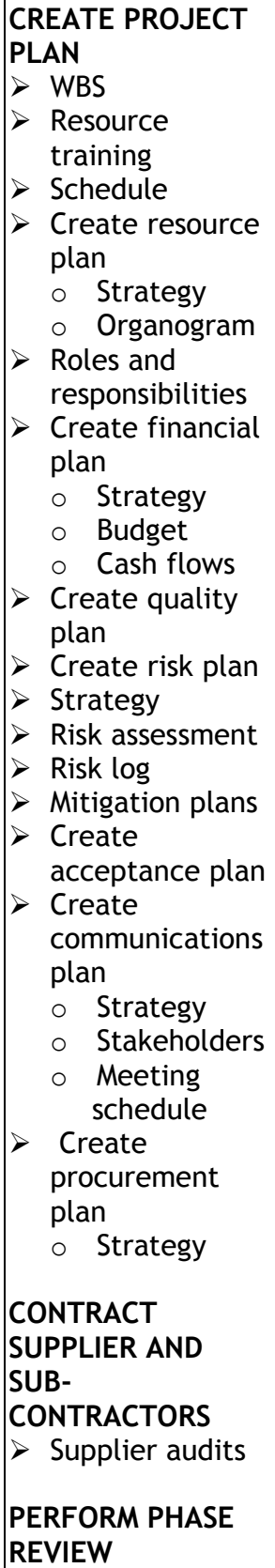 & $\begin{array}{l}\text { BUILD } \\
\text { DELIVERABLES, } \\
\text { MONITOR, AND } \\
\text { CONTROL } \\
\\
>\text { Perform time } \\
\text { management } \\
>\text { Perform cost } \\
\text { management } \\
>\text { Perform quality } \\
\text { management } \\
>\text { Perform change } \\
\text { management } \\
>\text { Perform risk } \\
\text { management } \\
>\text { Perform } \\
\text { procurement } \\
\text { management } \\
>\text { Perform } \\
\text { acceptance } \\
\text { management } \\
>\text { Perform } \\
\text { communication } \\
\text { management }\end{array}$ & $\begin{array}{l}\text { PERFORM PROJECT } \\
\text { CLOSURE } \\
\text { REVIEW PROJECT } \\
\text { COMPLETION }\end{array}$ \\
\hline 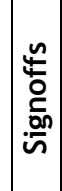 & $\begin{array}{l}\text { Client } \\
\text { Project sponsor } \\
\text { Business unit } \\
\text { manager } \\
\text { Project manager }\end{array}$ & $\begin{array}{l}\text { Client } \\
\text { Project sponsor } \\
\text { Business unit } \\
\text { manager } \\
\text { Project manager }\end{array}$ & $\begin{array}{l}\text { Client } \\
\text { Project sponsor } \\
\text { Business unit } \\
\text { manager } \\
\text { Project manager }\end{array}$ & $\begin{array}{l}\text { Client } \\
\text { Project sponsor } \\
\text { Business unit } \\
\text { manager } \\
\text { Project manager }\end{array}$ \\
\hline
\end{tabular}

Table 1: Detail of proposed project management methodology 


\subsection{Analysis of round 1 data in order to develop round 2 questionnaires}

A lack of project management maturity is one of the most pressing and challenging issues when applying a project management methodology in the South African mining industry.

\begin{tabular}{|l|l|l|l|}
\hline $\mathbf{1}$ & $\mathbf{2}$ & $\mathbf{3}$ & $\mathbf{4}$ \\
\hline Disagree strongly & Disagree & Agree & Agree strongly \\
\hline
\end{tabular}

Respondents had to choose any option ranging between strong disagreement (score of 1) to strong agreement (score of 4).

\subsection{Summary of results}

All six of the round 2 questionnaires were received back within two weeks. There was disagreement on only two of the eight questions for round 2 . There was positive agreement on three of the questions, and total agreement on the remaining three questions.

The following categories were created to determine the consistency of the responses of the respondents regarding round 2 :

- $\quad$ No agreement:

0 when the maximum difference is 2 for two of the respondents, or

- agreement/disagreement was selected by two or more respondents

- Positive agreement:

0 when agreement and strong agreement were chosen by more than five respondents

- $\quad$ Full agreement:

$\circ \quad$ when five of the six respondents chose agreement or strong agreement

- Full disagreement:

$\circ \quad$ when five of the six respondents chose disagreement.

Based on the research results, the following conclusions can be drawn:

- $\quad$ Respondents were in positive agreement that a lack of project management knowledge and experience are the most pressing and challenging issues when applying a project management methodology in the South African consulting engineering industry

- Respondents were in positive agreement that a lack of project management maturity inhibits the application of a project management methodology in practice

- Respondents were in full agreement that the following typical project life cycle phases are required for consulting engineering projects:
- Initiation
Planning
Execution
- Close-out

- Respondents were in full agreement that the major aspects, shown in

- Figure 1, need to be considered for consulting engineering projects

- Respondents were in full agreement that the current culture in a company's management inhibits the application of a project management methodology in practice.

- Respondents were in positive agreement that, by attaining management buy-in, one can deal effectively with the application of a project management methodology for consultation projects in South Africa.

- Respondents were in full agreement that, by applying a project management methodology in the South African consulting engineering industry, more consistent solutions (time, cost, and quality) will be presented to the client. 


\section{SUMMARY AND RECOMMENDATIONS}

A survey was conducted in which respondents with more than five years' project management experience were questioned in two consecutive rounds on the characteristics of a project management methodology in the consulting engineering industry. Six respondents took part in round two of the Delphi type survey.

The survey was conducted in several consulting engineering companies in South Africa, each with an annual turnover of R50 million, and with diverse activities ranging form software development, hardware design, and construction t,o thermal fluid consulting. The average size of projects exceeds R1 million, with an average duration of more than one year. Contracting strategies included turnkey, target price, and cost reimbursable plus fee.

Round 1 of the Delphi survey posed six open-ended questions to respondents regarding the definition and application of a project management methodology in the consulting engineering industry in South Africa. The answers to these questions were used to identify keywords and categories of the keywords pertaining to project life cycles and methodology application. Categories of keywords that appeared more than twice were used to define eight Likert-scale questions for round two of the Delphi survey.

Recommendations for future research include that the detail of the proposed methodology should be compared with more methodologies that are used in practice, to determine the applicability of the proposed methodology. Furthermore, the Delphi survey should be expanded to include more respondents in order to refine the proposed methodology and to enhance its wider application.

\section{REFERENCES}

[1] Nicholas, J.M. \& Steyn, H. 2008. Project management for business and technology Principles \& practices, $3^{\text {rd }}$ ed., London: Butterworth-Heinemann.

[2] Condon, E. \& Hartman, F. 2004. Playing the game. Proceedings of PMI Research Conference, London, UK. Project Management Institute. July 2004.

[3] Flyvbjerg, B., Holm, M.K. \& Buhl, S.L. 2002. Understanding costs in public works projects: Error or lie? In Williams, T. 2004. Assessing and building on the underlying theory of project management in the light of badly over-run projects Proceedings of PMI Research Conference 2004,. London, UK. Project Management Institute.

[4] Miller, R. \& Lessard, D. July 2000. The anatomy of major projects: A study of the reality of project management. In Condon, E. Playing the game, Proceedings of PMI Research Conference 2004, London, UK. Project Management Institute.

[5] Shenhar, A.J. 2003. Strategic project leadership: Focusing projects on business results. PMI Global Congress, Hague, Netherlands, May 2003.

[6] Jaafari, A., Doloi, H. \& Gunaratnam, D. 2004. Life cycle project management: A platform for strategic project management. Proceedings of PMI Research Conference, London, UK. Project Management Institute. July 2004.

[7] Labuschagne, C. \& Brent. A.C. 2004. Sustainable project life cycle management: Aligning project management methodologies with the principles of sustainable development. Proceedings of the 2004 PMSA International Conference, Johannesburg, South Africa, May 2004, pp.104-115.

[8] Cook-Davies, T.J. \& Arzymanow, A. 2003. The maturity of project management in different industries: An investigation into variations between project management models. International Journal of Project Management, 21, pp.471-478.

[9] Kliem, R.L., Ludin, I.S., \& Robertson, K.L. 1997. Project management methodlogy: A practical guide to the next millennium. USA. Marchel Dekker Incorporated.

[10] Sasol. 2001. Business development and implementation. Sasol Technology (Pty) Ltd.

[11] White, D. \& Fortune, J. 2002. Current practice in project management - an empirical study. International Journal of Project Management, 20, pp.1-11.

[12] PMI. 2004. A guide to the project management body of knowledge (PMBOK® Guide). $3^{\text {rd }}$ ed. Newton Square, PA, USA: Project Management Institute. 
[13] Smith, G.S. \& Merritt, M.M. 2002. Proactive risk management: Controlling uncertainty in product development. Productivity Press, New York, USA.

[14] Scholl, W., König, C., Meyer, B. \& Heisig, P. 2004. The future of knowledge management: An international Delphi study. Journal of Knowledge Management, 8(2), pp. 19-35.

[15] Mullen, P.M. 2003. Delphi: Myths and reality, Journal of Health Organization and Management, 17(1), pp. 37 - 52.

[16] Cavalli-Sforza, V. \& Ortolano, L. 1984. Delphi forecasts of land-use - transportation interactions, Journal of Transportation Engineering, 110(3), pp. 324-339, in Mullen, P. M., 2003, Delphi: Myths and reality, Journal of Health Organisation and Management, 17(1), pp. 37-52.

[17] Phillips, R. 2000, New applications for the Delphi technique, Annual "San Diego" Pfeiffer and Company, vol. 2, pp. 191-196, in Mullen, P. M. 2003, Delphi: Myths and reality, Journal of Health Organisation and Management, 17(1), pp. 37-52.

[18] Linstone, H.A. 1978. The Delphi technique, in Fowles, R.B. (ed.), Handbook of futures research, Greenwood, Westport, CT, pp. 271-300.

[19] Shenhar, A. J., Lechler, T. \& Poli, M. 2002. One size does not fit all: True for projects, true for frameworks. Proceedings of PMI Research Conference, Project Management Institute. 
http://sajie.journals.ac.za 